\title{
ANTIHYPOXIC ACTIVITY OF THE VMA-10-18 DERIVATE UNDER HYPOBARIC HYPOXIA IN MICE
}

\section{Anastasia Gerashchenko ${ }^{1 凶}\left(\mathbb{D}\right.$, Natalia Shabanova $^{1}(\mathbb{D}$, Andrey Voronkov ${ }^{2}$}

1 Pyatigorsk Medical and Pharmaceutical Institute — branch of
Volgograd State Medical University, Pyatigorsk
${ }^{2}$ The Volgograd State Medical University, Volgograd, Russia

$\triangle$ anastasia_gerashchenko@mail.ru

ABSTRACT - The present study was carried out to evaluate the effect of a new derivative VMA-10-18 $(10 \mathrm{mg} / \mathrm{kg})$ on the resistance of mice to acute hypobaric hypoxia. It was confirmed that the studied derivative contributes to an increase in the life time on the lethal test site by 2,7 times $(p<0,05)$ compared with the control group of animals and exceeds the strength of the effect of the reference drug Metaprot by $1,2(\mathrm{p}<0,05)$.

KEY W ORDS - hypobaric hypoxia, mice, derivative VMA-10-18, Metaprot.

\section{INTRODUCTION}

The pathogenetic basis of most diseases and various kinds of conditions is hypoxia [1]. This problem plays an important role in various fields of human activities: military, sports, space, etc. [2,3]. In people who are often exposed to hypoxia, disturbances in ion channel conductance, acid-base homeostasis are observed. This affects all systems of the body and inhibits its recovery after induced physical and mental stress.

Antihypoxic agents are used in clinical practice to support the viability of the organism in condition of hypoxia. However, the arsenal of such drugs is limited, or the breadth and effectiveness of therapeutic doses are small $[2,3,4]$. Therefore, the search for new compounds with a wider range of antihypoxic doses and the absence of side effects is an urgent task of experimental and clinical pharmacology, which served as the basis for this experiment $[5,6,7,8]$.

To study the antihypoxic activity of a new derivative

Objective: VMA-10-18 under conditions of hypobaric hypoxia in mice.

\section{MATERIALS AND METHODS}

The experiment was performed in accordance with the Guidelines for preclinical studies of drugs, ed.
Received 11 October 2020;

Received in revised form 5 November 2020; Accepted 11 November 2020
A.N. Mironov (2012 Ed.) [9]. The animals were kept in the vivarium of the Pyatigorsk Branch of the Volgograd state medical University (Russia). The study was conducted on 30 mongrel white mice $(\mathrm{m}=20-24 \mathrm{~g})$. The animals were divided into 3 groups $(\mathrm{n}=10)$. During the experiment, all experimental animals were kept under standard vivarium conditions (natural light change mode, temperature, relative humidity, standard diet of laboratory animals, weekly change of bedding and cages, fixed feeding and drinking times) in compliance with the International recommendations of the European Convention for the protection of vertebrates used in experimental studies. The first group - control, received a solution of sodium chloride in an equimolar volume, the second group was injected with VMA-10-18 $(10 \mathrm{mg} / \mathrm{kg})$, synthesized at the department of organic chemistry of the Pyatigorsk Medical and Pharmaceutical Institute (Russia); the third the reference drug Metaprot (JSC «Pharmproject», Russia) $(25 \mathrm{mg} / \mathrm{kg})$ [3]. All objects were introduced intragastrically one hour before the experiment. Acute hypobaric hypoxia was modeled by «lifting» mice in a hyperbaric chamber $(\mathrm{h}=11000 \mathrm{~m}, \mathrm{v}=100 \mathrm{~m} / \mathrm{s})$ [10]. All findings were processed by means of variation statistics methods using the STATISTICA 6.0 software.

\section{RESULTS}

When hypobaric hypoxia was reproduced, the life time of the NC group animals was 28,9 $\pm 1,62 \mathrm{sec}$. When using Metaprot, the life expectancy of animals exceeded the analogous indices of the NC group of mice under conditions of hypobaric hypoxia by 2,2 times $(p<0,05)$. Testing for the resistance of mice to acute hypobaric hypoxia showed that the average lifespan of animals receiving the experimental VMA10-18 derivative intragastally was 78,3 $\pm 1,83$ seconds, which was 2,7 times $(\mathrm{p}<0,05)$ statistically significantly higher than the control group.

At the same time, the life expectancy of animals receiving VMA-10-18 exceeded the value of the Metaprot group by $1,2(\mathrm{p}<0,05)$, which was statistically significant.

\section{CONCLUSION}

The use of a new derivative VMA-10-18

$(10 \mathrm{mg} / \mathrm{kg})$ significantly increased the lifespan of mice: 


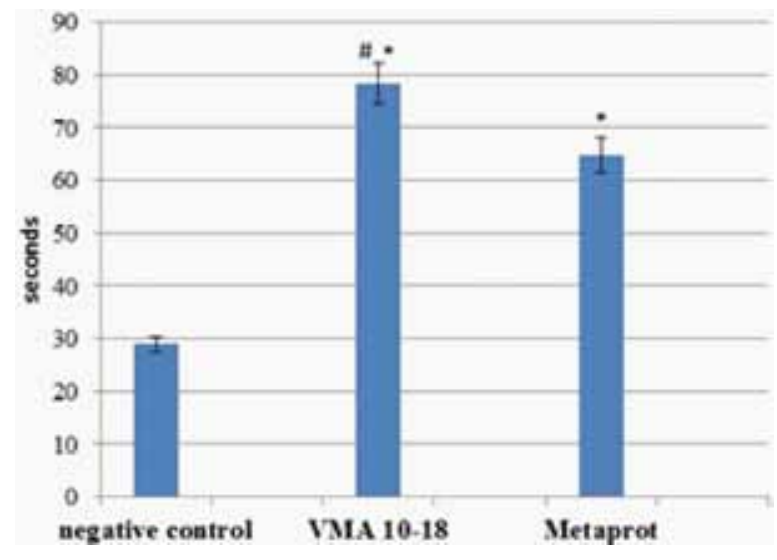

Fig. 1. Assessment of the effect of the new derivative VMA-10-18 and Metaprot on the lifespan of mice under hypobaric hypoxia

Note: Control - a control group of mice, Metaprot - a group of mice that received Metaprot; VMA-10-18 - a group of mice treated with VMA-10-18; * - statistically significant for the control group of mice $(p<0,05)$; \# - statistically significant for the group of mice treated with Metaprot $(p<0,05)$.

by 2.2 times compared to the control group and 1,2 times versus the mice receiving Metaprot. The outcomes may indicate the antihypoxic effect of this compound exceeds that of the reference drug Metaprot at a dose of $25 \mathrm{mg} / \mathrm{kg}$. Since the antihypoxic effect can be one of the mechanisms of actoprotective activity, this compound is a promising object for further study and correction of mental and physical performance.

\section{REFERENCES}

1. Baron D. A., Martin D. M., Abol Magd S. Doping in sports and its spread to at-risk populations: an international review // World Psychiatry. - 2007. Vol. 6. - P. 118-123.

2. Allwood MA, Edgett BA, Eadie AL, et AL. Moderate and severe hypoxia elicit divergent effects on cardiovascular function and physiological rhythms.J Physiol. 2018;596(15):3391-3410. doi:10.1113/ JP275945.

3. Shabanov P.D., Marysheva V.V. Protective properties of thiazolindole antihypoxants against damaging chemical factors. // Medico-biological and socio-psychological problems of safety in emergency situations. - 2008. - № 3. (In Russ.) doi:10.29235/1561-83312019-55-4-436-441

4. Shustov E.B et AL. Physical exercise hypoxia in athletes and laboratory animals // Biomedicine. - 2014. - Vol. 4. - P. 4-16. (In Russ.)

5. Ouellet, J. Patients presenting to an outpatient sport medicine clinic with concussion [Cas de commotion en clinique externe de médecine du sport]: Retrospective observational analysis / J. Ouellet, L. Boisvert, L. Fischer // Can. Fam. Physician. - 2016. - Vol. 62, № 6. - P. e340-e345.
6. SAmoilov N.N. ET AL. Study of the antihypoxic activity of new imidazole derivatives on the model of hypoxia with hypercapnia // Bulletin of the Russian Academy of Natural Sciences. - 2008. - №. 3. P. 71-72. (In Russ.)

7. ZHUR K.V ET AL. Influence of hypoxia on the expression of a number of genes associated with sports success // Applied sports science. - 2015. - №. 1. (In Russ.)

8. Katunina N.P. Experimental study of antihypoxic activity of new derivatives of 3-hydroxypridine in the model of acute hypoxia with hypercapnia and acute hypobaric hypoxia / Reviews on the wedge. headlight-makol. and lek. therapy. - 2011. - Vol. 9, № 1 - P. 69-72. (In Russ.)

9. Mironov A.N. The guidelines for preclinical studies of pharmaceuticals. Part one. - M.: Grif and K, 2012. - 944 p. (In Russ.)

10. ODrinsky P.N. Influence of Allim-2 on the life expectancy of mice in acute hypobaric hypoxia / / Nauka i sovremennost. -2010 . - №. 5-2. - P. 310-313. (In Russ.) 